\title{
Potentiometric Study of Cetylpyridinium Chloride Cooperative Binding to Anionic Azo-Dyes
}

\author{
Reza Hosseinzadeh, ${ }^{*, a, b}$ Abdol-Khalegh Bordbar, ${ }^{c}$ Amir Abbas Matin ${ }^{a}$ and Ramin Maleki ${ }^{a}$ \\ ${ }^{a}$ Food and Chemical Analysis Research Lab. Jahad-e-Daneshgahi, Urmia, Iran \\ ${ }^{b}$ Chemistry Society, Iranian Choice Part of Young Researchers' Center, Urmia, Iran \\ ${ }^{c}$ Laboratory of Biophysical Chemistry, Department of Chemistry, University of Isfahan, \\ Isfahan, 81746-73441, Iran
}

\begin{abstract}
A ligação do cloreto de cetilpiridinio (CCP) com alguns corantes azo (X6G, 3-BL, DY-42) tem sido extensivamente estudada em várias concentrações de corantes, usando eletrodo de membrana seletiva a cetilpiridinio. Este método se apresenta rápido e preciso. Gráficos logarítmicos de Klotz foram construídos a partir de medidas de EMF. Estes gráficos indicaram cooperatividade em todas as interações. Isotermas de ligação precisas foram obtidas e analisadas usando-se a equação de Hill. Os valores dos parâmetros da equação de Hill foram estimados e determinados, considerando-se o fato de que o parâmetro de saturação da ligação na equação de Hill (y) pode ser determinado a partir da razão de medidas da força eletromotriz, na presença e ausência do corante. Em todas as interações, os coeficientes de Hill indicam ligação cooperativa nas interações CCP-corante devido à combinação das interações eletrostáticas e hidrofóbicas. As energias de Gibbs intrínsecas aos processos de ligação foram calculadas.
\end{abstract}

The binding of cetylpyridinium chloride (CPC) with some azo dyes (X6G, 3-BL, DY-42) has been extensively studied at various concentration of dyes, using cetylpyridinium-selective membrane electrode as a fast and accurate method. Klotz logarithmic plots have been constructed from EMF measurements. These plots indicated cooperativity in all of interactions. The accurate binding isotherms have been obtained and analyzed using Hill equation. The values of Hill equation parameters have been estimated and determined by considering this fact that saturation parameter of binding in the Hill equation (y) can be determined from the ratio of electromotive force (EMF) measurements in the presence and absence of dye. In all of the interactions Hill coefficients indicate cooperative binding in CPC-dye interactions due to the combination of both electrostatic and hydrophobic interactions. Intrinsic Gibbs energies of binding processes have been also calculated and interpreted on basis of interaction mechanism.

Keywords: cetylpyridinium chloride, cooperative binding, binding isotherm, Hill equation, dye-surfactant

\section{Introduction}

The various unit operations of textile industry offer numerous opportunities for advantageous use of surfaceactive agents because they show interesting interfacial and bulk properties. As a consequence, a larger number of such products are used in textile processing than in any other industry. ${ }^{1,2}$

Surfactants are widely used in household and industrial cleaners, cosmetics, research laboratories and as wetting, dispersing and leveling agents for improving dyeing process by increasing solubility, stabilizing the

*e-mail: chem.reza@gmail.com; r.hoseinzadeh@acecr.ac.ir dispersed state and promoting uniform distribution of the dye in the textile..$^{2-4}$

Extensive research has already been carried out on surfactant-dye interactions.

The studies in this area are still very important and interesting in the context of the theory and technology of dyeing. ${ }^{4-7}$ In the theory of textile coloration, studies on dye-surfactant interactions in aqueous solutions represent the very important research topic. The complex formation processes between dyes and surfactants of different structures are investigated in binary mixtures. ${ }^{5-14}$

In recent years these interactions have been studied, mostly spectroscopically. ${ }^{4,10,12}$ These researchers have detected spectral changes of ionic dyes when the 
oppositely-charged or nonionic surfactants are added to aqueous dye solutions. The change in absorption band accompanied by the change of the color of the dye can be explained as the result of dye-surfactant interactions. In previous works also the interactions between surfactant and polymers and other macromolecules were investigated by ion-selective electrodes. However, there were some reports about investigation of dye-surfactant interactions using potentiometric method. ${ }^{4-7}$ In the present work, a potentiometric titration was used to obtain the results of interactions between cationic surfactant, cetylpyridinium chloride (CPC) and three dyes, (3-BL, DY-42, X6G). The EMF data have been used for plotting binding isotherms, calculation of Hill equation parameters and Gibbs energy of binding process.

\section{Experimental}

\section{Materials and apparatus}

Solophenyl red 3BL (C. I. Direct 80, M.W. $=1373$ g $\mathrm{mol}^{-1}$ ), light yellow X6G (C. I. Reactive Yellow 2, M.W.=872.5 $\mathrm{g} \mathrm{mol}^{-1}$ ) and DY42 (C. I. Direct Yellow 42, M.W.=650.5 $\mathrm{g} \mathrm{mol}^{-1}$ ) textile dyes were obtained from Ciba-Geigy (UK), Youhao (China) and Bitterfeld (Germany), respectively. The structures of the dyes, used in this study, are shown in Figure 1. Reagent grade dioctylphetalate (DOP) and high relative molecular weight PVC were purchased from Fluka and used as received. Cetylpyridinum chloride (CPC, see Figure 1) was obtained from Sigma Chemical Co. Tetrahydrofuran (THF) and all the salts (from Merck) were of the highest purity and used
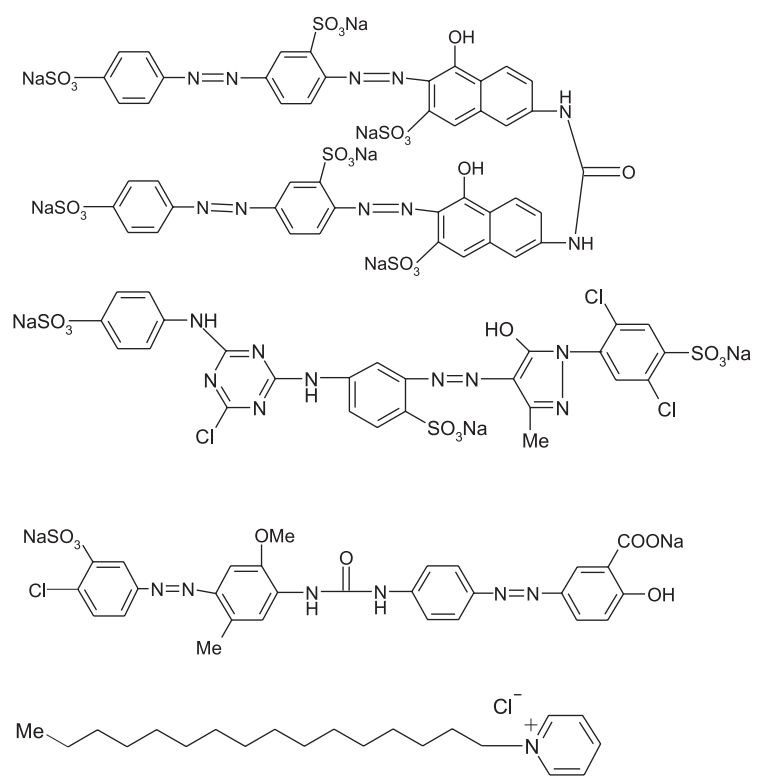

Figure 1. Chemical structures of (a) 3BL, (b) X6G, (c) DY-42 and (d) CPC without further purification. Standard solutions and buffers were prepared using doubly distilled water.

All potentiometric and $\mathrm{pH}$ measurements were made at $25^{\circ} \mathrm{C}$ using Metrohm 744 (Switzerland). $\mathrm{Ag} / \mathrm{AgCl}$ reference electrodes were purchased from Azar Electrode Co. (Urmia, Iran). The dyes solutions were freshly prepared and used.

\section{Methods}

The membrane electrode selective to cetylpyridinum (CP) ion was constructed using literature methods. ${ }^{15-17}$ The membrane contains specially conditioned PVC and DOP as a commercially available polymeric plasticizer. The principle of this electrode shows that the monomer $\mathrm{CP}$ activities in various solutions can be obtained from EMF measurements on the following cell compartment:

$\mathrm{Ag} / \mathrm{AgCl}$ | internal solution | PVC membrane | testing solution of $\mathrm{CPC} \mid \mathrm{AgCl} / \mathrm{Ag}$

\section{Results and Discussion}

At CPC concentrations below the critical micelle concentration (CMC), the CPC was dissociated completely; therefore plotting of EMF against the logarithm of concentration of CPC gives Nernstian slope at below the CMC of CPC $(57-60 \mathrm{mV}$; due to this fact that the slope of electrode has been determined from EMF measurements for at least 5 electrodes so we consider the region of slope that most of the electrodes showed). However, at higher concentration, the resulting plots show a distinct break at the CMC (Figure 2; the CMC value that can be obtained from this figure is $9.8 \times 10^{-4} \mathrm{~mol} \mathrm{~L}^{-1}$, which is in good agreement with previously reported values). Figure 2 shows the EMF as a function of $\log$

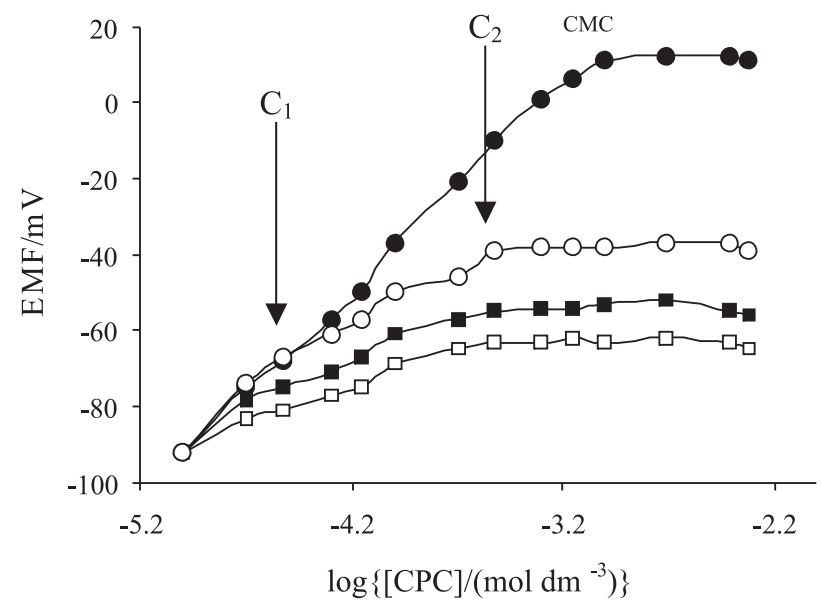

Figure 2. The variation of EMF vs. $\log [\mathrm{CPC}]$, at $25^{\circ} \mathrm{C}$ and $\mathrm{pH} 6.9$ in the absence and presence of X6G dye, (dye concentration: $(\mathrm{O}) 1 \times 10^{-6} \mathrm{~mol}$ $\mathrm{dm}^{-3},(\square) 5 \times 10^{-6} \mathrm{~mol} \mathrm{dm}^{-3}$ and $(\square) 1 \times 10^{-5} \mathrm{~mol} \mathrm{dm}^{-3}$ ). 
$[\mathrm{CPC}]_{t}$ in the absence and presence of various concentrations of X6G dye, at $\mathrm{pH} 6.9$ and $25^{\circ} \mathrm{C}$. The similar curves were obtained for other dyes-CPC interactions.

The curve in the presence of dye is consisting of three distinct regions as following: (i) The first region, which is at very low concentrations of CPC, shows Nernstian slope, which is approximately equal to the corresponding value in the absence of dye. Hence, it can conclude that there is no measurable interaction between dye and CPC at this region. (ii) The second region begins with a distinct break, shown as $\mathrm{C}_{1}$ in the plot. This deviation from linearity is due to the interaction of CPC with dye and continues until the second distinct break shown as $\mathrm{C}_{2}$ is reached. In the other hands surfactant monomers interact with dye molecules and so free monomer form of surfactant decreased in solution and caused the deviation of Nernstian slope in EMF measurements. At the $\mathrm{C}_{2}$ point, surfactant and dye molecules introduce dyesurfactant aggregates that indicate the concentration of surfactant cause the aggregation between dye and surfactant molecules. This point $\left(\mathrm{C}_{2}\right)$ has been known as critical aggregation concentration (CAC). (iii) The third region is located after $\mathrm{C}_{2}$, where the monomer concentration is approximately constant as the total concentration of CPC is increased. This is the concentration at which the dye becomes saturated with surfactant.

By considering the fact that EMF is reduced in the presence of dye the amount of CPC bond to dye can be calculated. Also by assuming that saturation of dye by surfactant has been accrued at second break of the corresponding curves, we can calculate the saturation parameter, $y$, in the Hill equation.

$y=\frac{\Delta E}{\Delta E^{\infty}}$

$\Delta \mathrm{E}$ is the difference of EMF measurements between curves in the absence and presence of dye and so $\Delta \mathrm{E}^{\infty}$ is the EMF difference at the second break of the interaction curves $\left(\mathrm{C}_{2}\right)$.

The average number of CPC molecules bound per dye molecule, $v$, has been calculated as:

$v=\frac{[C P C]_{t}-[C P C]_{f}}{[d y e]_{t}}$

where $[\mathrm{CPC}]_{\mathrm{t}},[\mathrm{CPC}]_{\mathrm{f}}$ and $[\mathrm{dye}]_{\mathrm{t}}$ are total and free concentration of $\mathrm{CPC}$ and total concentration of dye, respectively.
Figures 3 and 4 show the variation of $v$, against of the $\log [\mathrm{CPC}]_{\mathrm{f}}$ (binding isotherm) and the corresponding Scatchard plots, $v /[\mathrm{CPC}]_{\mathrm{f}}$ versus $v$, at various experimental conditions which have been explained in the legends of these figures. All of the Scatchard plots are unusual, so the results used to analyze the binding data calculating saturation factor (y, equation 1) and fitting to Hill equation (equation 3). ${ }^{18}$

$\ln \frac{y}{1-y}=\ln K_{H}+n_{H} \ln [C P C]$

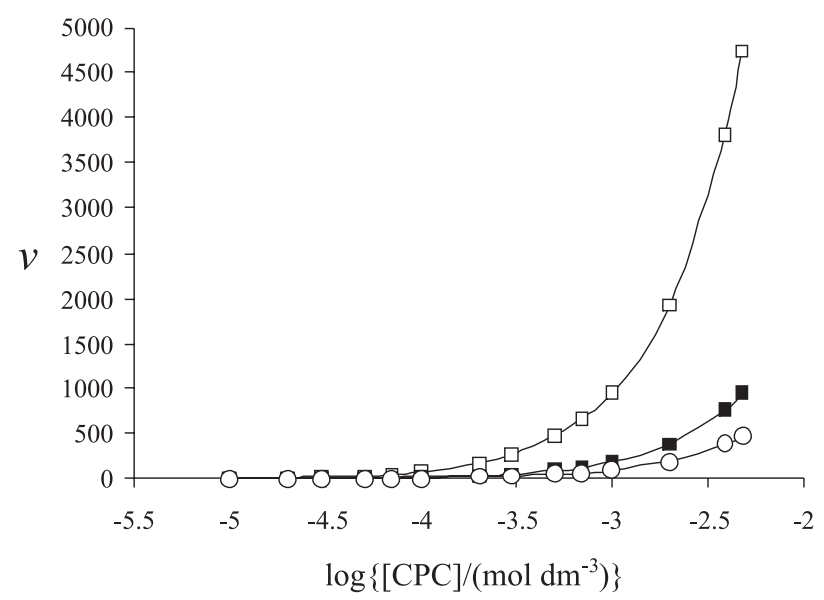

Figure 3. Binding isotherms for interaction of $\mathrm{CPC}$ with $\mathrm{X} 6 \mathrm{G}$ dye at $25^{\circ} \mathrm{C}, \mathrm{pH} 6.9$ and various concentration of dye: $(\mathrm{O}) 1 \times 10^{-6} \mathrm{~mol} \mathrm{dm}^{-3}$, (ם) $5 \times 10^{-6} \mathrm{~mol} \mathrm{dm}{ }^{-3}$ and ( $\left.\square\right) 1 \times 10^{-5} \mathrm{~mol} \mathrm{dm}^{-3}$.

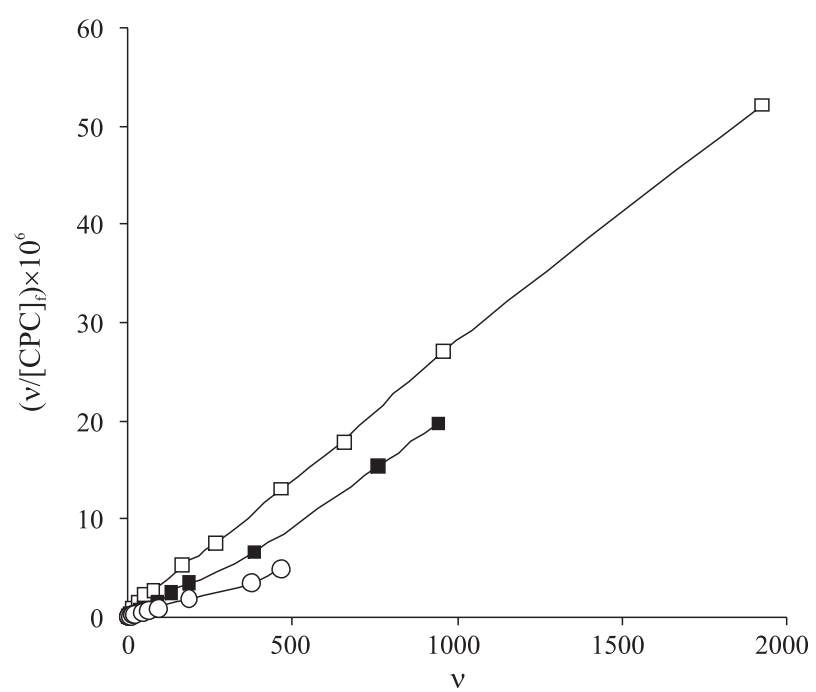

Figure 4. Scatchard plots for interaction of $\mathrm{CPC}$ with $\mathrm{X} 6 \mathrm{G}$ dye at $25^{\circ} \mathrm{C}$, pH 6.9 and various concentration of dye: (O) $1 \times 10^{-6} \mathrm{~mol} \mathrm{dm}^{-3}$, (口) $5 \times 10^{-6} \mathrm{~mol}$ $\mathrm{dm}^{-3}$ and $(\square) 1 \times 10^{-5} \mathrm{~mol} \mathrm{dm}^{-3}$.

The collective estimated binding parameters of Hill equation are listed in Table 1.

Also by calculation of saturation parameter (y) we can plot the $\mathrm{y}$, versus $\log [\mathrm{CPC}]$ that is known as Klotz logarithmic plot. Figure 5 shows the Klotz logarithmic 
plot for interaction of CPC by X6G at various concentration of dye. All of these plots are sigmoidal that indicate cooperativity in binding process. The similar curves were obtained for other dyes-CPC interactions. ${ }^{18,19}$

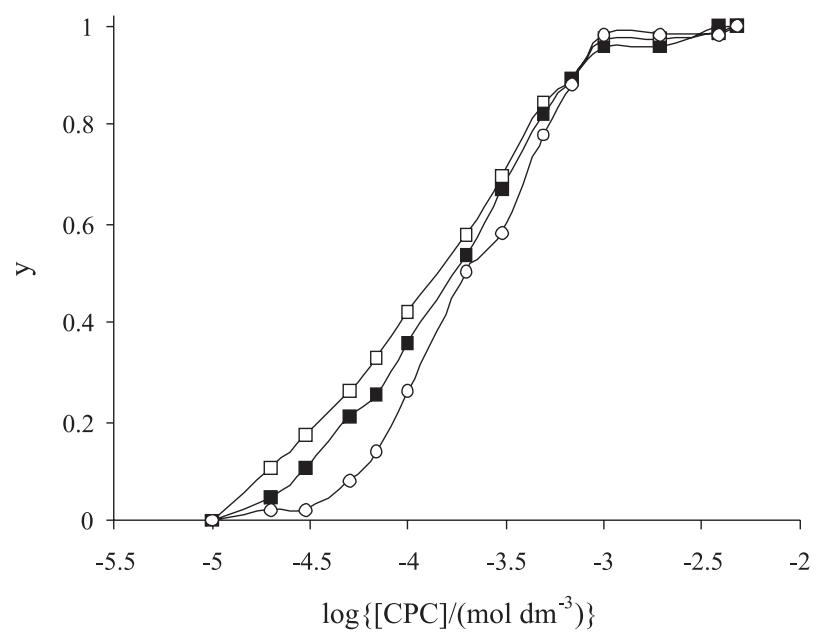

Figure 5. Klotz logarithmic plot for interaction of $\mathrm{CPC}$ with $\mathrm{X} 6 \mathrm{G}$ dye at $25^{\circ} \mathrm{C}$, pH 6.9 and various concentration of dye: (O) $1 \times 10^{-6} \mathrm{~mol} \mathrm{dm}^{-3}$, (ם) $5 \times 10^{-6} \mathrm{~mol} \mathrm{dm}^{-3}$ and ( $\left.\square\right) 1 \times 10^{-5} \mathrm{~mol} \mathrm{dm}^{-3}$.

The intrinsic Gibbs energy of binding per mol of CPC $\left(\Delta \mathrm{G}_{\mathrm{b}}^{\circ}\right.$ ) can be obtained by the following equations: ${ }^{22}$

$\Delta G_{b}^{\circ}=-R T n_{H} \ln K_{H}+R T\left(1-n_{H}\right) \ln [C P C]_{f}$

Figure 6 shows the variation of $\Delta \mathrm{G}^{\circ}{ }_{\mathrm{b}}$ versus $\ln [\mathrm{CPC}]_{\mathrm{f}}$ for interaction of $\mathrm{CPC}$ with $\mathrm{X} 6 \mathrm{G}$ at various concentration of $\mathrm{X} 6 \mathrm{G}$ dye. The similar curves were obtained for other dyes-CPC interactions.

At last it can be concluded that all of the binding processes show positive cooperativity in both binding sets $\left(n_{\mathrm{Hi}}>1\right)$ for all of the studied conditions. The positive cooperativity in the binding process represents that both

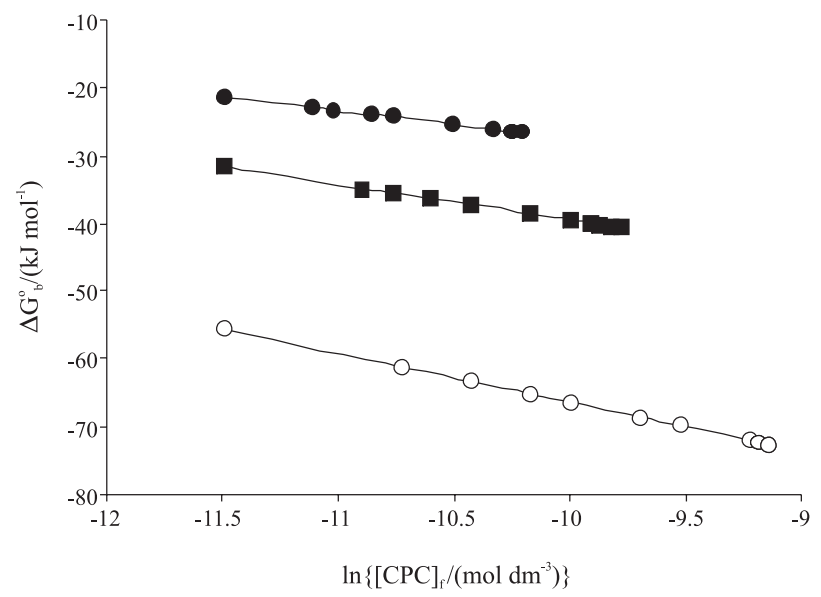

Figure 6. The variation of intrinsic Gibbs energy of binding per mole of $\mathrm{CPC}, \Delta \mathrm{G}^{\circ}{ }_{\mathrm{b}}$, as a function of $\ln [\mathrm{CPC}]_{\mathrm{f}}$ for binding of $\mathrm{CPC}$ to $\mathrm{X} 6 \mathrm{G}$ at $25^{\circ} \mathrm{C}, \mathrm{pH}$ 6.9 and various concentration of X6G: (O) $1 \times 10^{-6} \mathrm{~mol} \mathrm{dm}^{-3},(\square) 5 \times 10^{-6} \mathrm{~mol}$ $\mathrm{dm}^{-3}$ and (O) $1 \times 10^{-5} \mathrm{~mol} \mathrm{dm}{ }^{-3}$. electrostatic and hydrophobic interactions contribute in the binding process. The $\Delta \mathrm{G}^{\circ}{ }_{\mathrm{b}}$ curves represent the relative variation of intrinsic Gibbs energy of binding. The slope of the lines in these curves relates to Hill coefficient. Table 1 shows that the binding strength for interaction between $\mathrm{X} 6 \mathrm{G}$ and $\mathrm{CPC}$ increased by increasing of dye concentration and for two other dyes (3BL and DY-42) binding strength decreased by increasing of dyes concentration. This behavior can be interpreted on the bases of this fact that by increasing of dyes concentration in the presence of CPC surfactant, self aggregation of dyes affected binding affinity and so decreased binding strength at high concentrations of these dyes (3BL and DY-42).

Table 1. Values of Hill parameters for interaction of CPC with dyes at $25^{\circ} \mathrm{C}$

\begin{tabular}{lccc}
\hline dye & $\begin{array}{c}{[\text { dye }] /} \\
\left(\mathrm{mol} \mathrm{dm}{ }^{-3}\right)\end{array}$ & $\ln \left(\mathrm{K}_{\mathrm{H}} / \mathrm{M}\right)$ & $\mathrm{n}_{\mathrm{H}}$ \\
\hline 3BL & $1 \times 10^{-6}$ & 5.33 & 1.36 \\
3BL & $5 \times 10^{-6}$ & 4.59 & 1.23 \\
3BL & $1 \times 10^{-5}$ & 4.09 & 1.10 \\
X6G & $1 \times 10^{-6}$ & 10.40 & 2.67 \\
X6G & $5 \times 10^{-6}$ & 11.90 & 3.14 \\
X6G & $1 \times 10^{-5}$ & 14.30 & 3.91 \\
DY-42 & $1 \times 10^{-6}$ & 15.23 & 4.12 \\
DY-42 & $5 \times 10^{-6}$ & 9.56 & 2.78 \\
DY-42 & $1 \times 10^{-5}$ & 7.71 & 2.35 \\
\hline
\end{tabular}

\section{Acknowledgment}

Financial supports of the Food \& Chemical Analysis Research Laboratory of Jahad-E-Daneshgahi of Urmia are gratefully appreciated.

\section{References}

1. Schwartz A. M., Perry J. W. In Surface Active Agents: Their Chemistry and Technology, Schwartz A. M.; Perry J. W., eds., Huntington : Krieger, 1979.

2. Tehrani Bagha, A. R.; Bahrami, H.; Movassagh B., Arami, M.; Menger F. M.; Dyes Pigm. 2007, 72, 331.

3. Goddard, E. O. In Interactions of Surfactants with Polymer and Proteins, Goddard, E. D.; Ananthapadamanabham, K. P., eds., CRC Press: Boca Raton, FL, 1993.

4. Ghoreishi, S. M.; Shabani Nooshabadi, M.; Dyes Pigm. 2005, $65,117$.

5. Simoncic, B.; Kert, M.; Dyes Pigm. 2006, 71, 43.

6. Simoncic, B.; Kert, M.; Dyes Pigm. 2002, 54, 221.

7. Simoncic, B.; Span J.; Dyes Pigm. 1998, 36, 1.

8. Bracko, S.; Span, J.; Dyes Pigm. 2001, 50, 77.

9. Navarro, A.; Sanz, E.; J. Colloid Interface Sci. 2001, 237, 1. 
10. Oakes, J.; Gratton, P.; Dixon, S.; Color. Technol. 2003, 119, 301.

11. Gokturk, S; Tuncay, M.; J. Surfactants Deterg. 2003, 6, 325.

12. Sabate, R; Estelrich, J.; J. Phys. Chem. B 2003, 107, 4137.

13. Forte-Tavcer, P.; Dyes Pigm. 2004, 63, 181.

14. Behera, P. K.; Mohapatra, S.; Patel, S.; Mishra, B. K.; J. Photochem. Photobiol., A 2005, 169, 253.

15. Ghoreishi, S. M.; Naeimi, H.; Navid, M. D.; Bull. Korean Chem. Soc. 2005, 26, 548.

16. Bordbar, A. K.; Hosseinzadeh, R.; Omidiyan, Kh.; Bull. Chem. Soc. Jpn. 2004, 77, 2027.
17. Bordbar, A.K.; Omidiyan, Kh.; Hosseinzadeh, R.; Colloids Surf., B 2004, 40, 67.

18. Moosavi-Movahedi, A. A.; Physical Chemistry of Biological Macromolecules, Tehran University Publications: Tehran, 1994

19. Chang, R.; Physical Chemistry with Applications to Biological Systems, MacMillan Publishing: New York, 1981, ch. 14.

20. Bordbar, A. K.; Saboury, A. A.; Housaindokht, M. R.; MoosaviMovahedi A. A.; J. Colloid Interface Sci. 1997, 192, 415.

Received: August 18, 2006 Web Release Date: March 16, 2007 